\title{
Should the Government Invest, or Try to Spur Private Investment?
}

\author{
MICHAEL CRAGG AND JOSEPH E. STIGLITZ
}

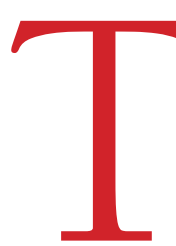
hough the word 'stimulus' has fallen out of favor, all agree that the U.S. economy needs stimulation. We suffer a deficiency in aggregate demand. Today, the debate is about how best to strengthen demand-especially at

Michael Cragg is a principal of The Brattle Group. He has extensive consulting, research, and expert-witness experience in financial services, corporate finance, and valuation. Prior to joining The Brattle Group, he was a professor at Columbia and UCLA and a consultant at RAND. Dr. Cragg holds a Ph.D. in Finance and Economics from Stanford University and an M.A. from the University of British Columbia.

Joseph E. Stiglitz is the Editor of The Economists' Voice and University Professor, Columbia University. He served on the 1995 IPCC Assessment Panel, chaired President Clinton's Council of Economic Advisers, and was Chief Economist of the World Bank. He won the Nobel Memorial Prize in Economics in 2001. He is the author of the global bestseller, Globalization and its Discontents. His latest book, Freefall: America, Free Markets, and the Sinking of the World Economy, was published by W.W. Norton \& Co. in 2010

๑ Berkeley Electronifofieffift to you by | Columbia University Law Library New York (Columbia University Law Library New York) a time when the country seems so focused on the size of its deficits and the national debt.

We need to look for programs that deliver a big bang for the buck now, and promote growth in the future. Such programs might lower the national debt in the medium to long run, even if the deficit increases today. Not surprisingly, policies and programs that seek to stimulate investment, both in the public and private sector, top the list.

President Obama has proposed a simple and, at first blush, intuitively appealing investment-stimulus policy of allowing businesses to accelerate depreciation tax deductions for investments made in 2011. While the support from business for this policy comes as no surprise, in our opinion there are better options that would have both lower fiscal costs and larger investment stimulus.

THE ADMINISTRATION'S PLAN AND ITS PROBLEMS

The Administration estimates that 1.5 mil-

I lion firms will accelerate deductions, thereby garnering $\$ 200$ billion in tax reductions at a cost to the government of only $\$ 30$ billion over the next 10 years. ${ }^{1}$ Accelerations in depreciation deductions act as an interest-free loan from the government to the private sector, with the loan to each taxpayer paid back by the taxpayer over time through higher future taxes (with no change in their pre-tax profits). The low cost that the Administration has calculated that the program will incur is the direct result of current low interest rates, which allow the government to borrow cheaply in order to lend to the private sector.

If investment is not stimulated, and government and firms each face the same interest rate, then the benefit to the private sector The Economists' Voice April, 2011 
is equal to the cost to the government. It is simply a matter of redistribution. With zero interest rates all around, more depreciation deductions would have no benefits-but neither would they have costs. Typically, though, firms pay higher interest rates than the government does. This means that the value to firms of an accelerated depreciation policy is greater than the (direct, first round) cost to the government. For large American corporations, however, the benefit is likely to be limited: Right now, the treasury yield curve is approximately 25 basis points (bp) for a year, 150bp for 5 years, and $400 \mathrm{bp}$ for 30 years. Meanwhile, corporate spreads are less than $100 \mathrm{bp}$ for credit rated higher than BBB. Furthermore, many of these firms are awash in cash. Therefore, for these highly-rated firms, the social value of an interest-free loan is likely to be quite low, since they already enjoy very low interest rates.

In the current context of high deficits and indebtedness, we should look askance at any redistribution of money from the public sector to the corporate sector. With tough budgetary constraints facing the government, providing government money to firms to invest displaces money available from the government's own investment programs. Thus, we have to consider the value we gain for each dollar spent in redistribution. Not only must there be increased investment, but the increase must also be large enough to compensate for the tightened budgetary position of the government. The economy benefits when-but only whenthe accelerated depreciation leads to more total investment. The critical question then is: How much investment will there be that otherwise would not have occurred? The answer is, probably not very much. If public investments in education or technology are cut back, then not only will output today be lower, but so too will growth in the future. As a result, future deficits and the size of the debt will be larger because of diminished tax collections. Thus, for accelerated depreciation to have a positive effect on the economy, it must induce private investment substantially-in amounts that exceed the 'gift' from the government.

Assuming that the firms most likely to utilize this deduction pay taxes at the top rate of $35 \%$ and have access to capital, accelerated depreciation will allow corporations to save at least $\$ 100$ billion in financing expenses without any change in their investment behavior. ${ }^{2}$
Thus, one can at once understand why corporations are excited by this gift from the taxpayers for merely doing what they would have done anyway!

\section{WHY A TARGETED POLICY OF INVESTMENT} DEDUCTIONS WOULD BE PREFERABLE TO THE ADMINISTRATION'S APPROACH

$\Lambda$ targeted policy of investment deductions Awould be better. For instance, one could only allow firms to take the accelerated deduction for increased investment. Large capital projects already under way can easily be excluded from the program. More broadly, firms might receive the benefit only for expenditures in excess of, say, $80 \%$ of their investment levels in earlier years.

Although better than the Administration's plan, even a targeted approach is still likely to have a limited impact-for capital constraints are often to blame for the lack of investment among the firms that are not undertaking it. Some will have made profits in the past, so a loss carry-forward provision for firms investing incrementally, and only for such firms, will spur investment (though at some cost to the Treasury). However, many firms that are 
at the investment margin, and for which investment subsidies provide the most bang for the buck, are also the riskier firms, and they currently face credit constraints in the form of tightened lending standards, higher interest rates and very high equity costs. Furthermore, these firms may also be at a stage where they are not yet earning profits that would be taxed. For such firms, accelerated depreciation is irrelevant.

Accelerated depreciation is, in some ways, an 'old economy' approach to stimulating investment. The biggest benefits go to those in heavy industry, with long-term investments, who have access to capital. The benefits to many small- to medium-sized enterprises-in, say, the service sector-with more short-lived investments and without access to credit, are nonexistent. In short, the proposed accelerated depreciation targets its benefit exactly in the areas where that benefit is not needed.

\section{ALTERNATIVES THAT ARE PREFERABLE TO BOTH THE ADMINISTRATION'S PLAN AND TARGETED INVESTMENT DEDUCTIONS}

There are several better policy alternatives I for periods of extreme economic malaise like today's. First, we suggest resurrecting an old idea from the Kennedy era-an incremental investment tax credit (ITC). The advantage of an investment tax credit is that it immediately lowers the price of all capital goods to all firms, whether or not they earn profits (if the credit is refundable), and whether or not the assets are short- or long-lived. This measure thus overcomes accelerated depreciation's inherent bias toward long-lived assets purchased by profitable firms. We emphasize, however, that the policy should be implemented as an incremental investment tax credit, under which the government pays a fraction of the cost of any incremental investment. Not to do so provides a very expensive gift to all investment, including that which is already occurring.

However, an incremental ITC alone is unlikely to have significant impacts because the firms at the investment margin that are likely to see the largest benefit-and that are most likely to respond by increasing investmentare also those that have some, but limited, access to capital. It is actually more important to direct attention to credit-constrained firms. This leads us to ask, are there additional policies that are likely to be of particular benefit to this class of firms?

There is an additional problem with both ITC and accelerated depreciation. Typically, in downturns, economists recommend temporary measures, like temporary investment tax credits or accelerated depreciation. These attempt to smooth the economic downturn by encouraging future investment to happen sooner than it would have otherwise. The credits provide an incentive for investing today-when resources are underutilized-rather than next year. But we are in the midst of what many consider to be a long-term downturn, and such measures are unlikely to have a large impact: They simply move investment around within the downturn, promoting investment now at the expense of investment a little later in the downturn. Similarly, the cash-for-clunkers program succeeded in stimulating more car purchases for a while, but when the program ended, car purchases fell. It has succeeded only in moving car purchases forward by a few months. With large corporations flush with cash and interest rates at historic lows, there should be great concern regarding the costs to the government of simply moving corporate investment around 
within the downturn. Small- to medium-sized enterprises, which can't access capital, face the most important constraints. It is this kind of constraint that policymakers need to address.

A targeted credit-enhancement facility, together with a targeted ITC, holds out the promise of actually raising investment by also enhancing access to credit among small- to medium-sized enterprises. The Administration has developed experience with this type of policy. For instance, according to the Government Accountability Office, in 2009, the recent Department of Energy loan-guarantee program for green energy projects received $\$ 190$ billion in applications for loan guarantees. Over the course of two years, the DOE built a projectfinancing capability with more than $100 \mathrm{em}$ ployees and contractors, which it deployed to help credit-constrained firms make early-stage investments. At the same time, the banking community became familiar with how such a program works. In short, this shows that the government has already created the necessary infrastructure for fostering quick, incremental investment in at least one area. Well-designed credit-enhancement programs involve some risk absorption by the government and, importantly, private lenders must still bear some risk to obviate the problems of moral hazard. (The mortgage crisis forcefully demonstrated this moral-hazard problem. But there, originators bore none of the risk-and even today, they are objecting to bearing as little as 5 percent. Comparable problems have been addressed in other loan guarantee programs where there was sensitivity to these problems, such as the U.S. SBA, the Canadian CSBF, and similar programs in many other countries.) ${ }^{3}$

An additional approach recognizes that accelerated depreciation is a direct benefit to the leasing industry, which, like banks, may not be extending leases because they are worried that small- to medium-sized enterprises may be unable to reliably service them. The solution to this investment impediment is for the government to partially underwrite lease guarantees. A policy of accelerated depreciation for bank investments on leases for assets they purchase on behalf of small- to medium-sized firms, together with lease guarantees, would open another channel for investment that is otherwise blocked.

The supply of credit from our banking system to businesses is lower today than it was three years ago and continues to remain weak. In spite of all the fanfare about saving the banks to ensure the flow of credit, that stream is still dry. The banks say this is partly because lending is just too risky - and that there are more profitable ways of making money, by trading rather than lending. Credit enhancement would at least weaken this excuse for not lending-and might actually lead to more lending and investment.

As we stated at the outset, the root of the current economic malaise is a deficiency in aggregate demand. The challenge is to find programs that maximize positive impact for any given adverse effect on the deficit and debt. We have explained why there are several alternatives that are superior to the Administration's proposal for accelerated depreciation. We conclude with still one more proposalone that would have no short-run budgetary impact, and that would likely have a positive long-run effect.

Currently, U.S. corporations have much more than $\$ 1$ trillion in unrepatriated dividends in foreign subsidiaries. The unrepatriated dividends are the result of the U.S. policy of taxing global earnings at a rate substantially higher 
than most of the rest of the world. ${ }^{4}$ Consider a policy that allows a tax-free repatriation of offshore earnings, if the corporation puts the tax that it would have otherwise paid for the repatriation into an investment pool. The investment pool must be used within a two-year period, for making investment in firms at the investment margin (e.g. small- to mediumsized firms that are credit-constrained). This would provide an incentive for broad investment coordination across small, medium and large firms that could remove the logjam caused by pessimistic expectations. For financial firms, the requirement would be to place the investment pools in the hands of the Small Business Administration, for use in lending to small businesses. The attractiveness of such policies is that they entail no immediate budget impact-and even possibly none in the future-while at the same time providing rewards that affect healthy firms in a way that will simultaneously change their behavior.

The federal budget situation places a premium on moving beyond 'old economy' ideas and taking advantage of some of the true innovations in finance. If we are to get a bang for the buck, we must make sure that there are no mindless giveaways. And accelerated depreciation or an investment tax credit comes close to being a mindless giveaway, unless it is targeted to projects and firms at the investment margin. But even targeted investment policies are currently inadequate, due to the hangover from the financial crisis-small- and medium-sized firms do not have access to the credit they need for investing. To get the economy going will require more than just speeches expressing optimism for the future, or cajoling firms or households to spend more money: We need carefully designed carrots and sticks. Poorlydesigned programs can be counterproductive: With government budgetary constraints appearing to be binding, cutbacks in government spending could more than offset any increases in private spending, and reduced public investment could more than offset increased private investment, weakening future growth. We have proposed several modest, low-cost measures, the benefits of which would almost surely outweigh the costs.

Letters commenting on this piece or others may be submitted at submit. cgi? context $=$ ev .
NOTES

1. See http://www.whitehouse.gov/sites/default/files/ fact sheet expensing 9-8-10.pdf

2. The Administration calculates that the $\$ 200$ billion in tax deductions will be taken at a cost of $\$ 30$ billion over ten years. Assuming that the firms most likely to utilize this deduction are in the top marginal bracket of $35 \%$, this represents approximately $\$ 575$ billion in investment that will likely occur anyway. The capital structure for this $\$ 575$ billion in investment would be $\$ 200$ billion in foregone tax payments-which is effectively a loan at $0 \%$-and $\$ 375$ billion in debt and equity financing. Thus, the aggregate borrowing costs for such projects would be reduced by approximately one-third. Assuming conservatively that the cost of capital is 5\%, and that this investment was already going to happen, this policy represents $\$ 100$ billion in interest-rate savings (annual savings of $5 \%$ on $\$ 200$ billion over 10 years) to corporations, for not changing their behavior-at a cost of $\$ 30$ billion to U.S. taxpayers.

3. See for instance World Bank Policy Research Paper 4771 "The Typology of Partial Credit Guarantee Funds around the World," Thorsten Beck, Leora F. Klapper, Juan Carlos Mendoza, published in 2008, and also "Facilitating Access to Credit," OECD Discussion Paper presented March 13-14, 2008 at the World Bank Workshop on Partial Credit Guarantees, http://www.oecd.org/dataoecd/52/5/45324327.pdf.

4. Most countries tax corporate earnings on a territorial basis, whereas the U.S. does so on a global basis, providing a foreign tax credit for taxes paid in countries taxing territorial income. Since U.S. corporate tax rates are some of the highest in the world, it provides U.S. corporations an incentive to invest and accumulate earnings abroad. When foreign investment opportunities are exhausted, as 
they appear to be today, these accumulated earnings

are invested in the equivalent foreign money market

mutual funds. On net, this is a fairly unproductive

use of capital. 